\title{
Homeobox Protein OTX2
}

National Cancer Institute

\section{Source}

National Cancer Institute. Homeobox Protein OTX2. NCI Thesaurus. Code C102953.

Homeobox protein OTX2 (289 aa, $32 \mathrm{kDa}$ ) is encoded by the human OTX2 gene. This protein is involved in both transcriptional regulation and embryonic development. 